\title{
Experimental evaluation of a commercially available PEM fuel cell for residential buildings application
}

\author{
Katarina Simic ${ }^{a, b}$, Jonas Houfa, Wim Beyne ${ }^{a, b}$, Jan Desmet ${ }^{c}$ and Michel De \\ Paepe $^{a, b}$ \\ a Department of Electromechanical, Systems and Metal Engineering, Sustainable Thermo-Fluid \\ Energy Systems research team, Ghent University, Ghent, Belgium, \\ Michel.DePaepe@UGent.be \\ b Flanders Make@UGent corelab EEDT MP, Flanders Make, Leuven, Belgium, \\ Michel.DePaepe@UGent.be \\ c Department of Electromechanical, Systems and Metal Engineering, EELAB/Lemcko, Ghent \\ University, Kortrijk, Belgium, \\ Jan.Desmet@UGent.be
}

\begin{abstract}
:
Residential buildings claim a large share of the total energy use. Fuel cells in combination with electrolysers and hydrogen storage have been proposed as a solution for a low carbon self-sustaining future. Fuel cell units are able to generate electrical energy by means of hydrogen fuel with little or no emission of greenhouse gasses. Besides generating electricity, fuel cell units produce a certain quantity of heat, which can be used for the heating purposes of residential dwellings. In order to properly integrate the fuel cell units in residential buildings, an understanding of the operational properties is necessary. In this contribution, the performance of a commercially available proton exchange membrane (PEM) fuel cell has been experimentally evaluated. A complete test setup, containing the fuel cell, a buffer electrical battery and a set of discrete loads was built. The fuel cell's operational behaviour and efficiency are determined for a wide range of applied resistive loads. In addition, the temperature on the exhaust side of the fuel cell is measured for assessing the potential use of the waste heat energy and thus the combined heat and power (CHP) generation application. Lastly, the use of this particular fuel cell unit in a locally based renewable hydrogen production and energy storage system is estimated on a representative residential building case study. For the generated electrical power range between $400 \mathrm{~W}$ and $2770 \mathrm{~W}$, the evaluated PEM fuel cell unit resulted in efficiencies between $27.5 \%$ to $32.5 \%$. The exhaust temperature of the fuel cell unit vary closely around $25^{\circ} \mathrm{C}$ and no waste heat can be recovered for further utilization of this particular unit.
\end{abstract}

\section{Keywords:}

Fuel cell; Hydrogen; Power generation; Energy use; Residential building.

\section{Introduction}

\subsection{Energy use of residential buildings and role of fuel cells}

The 2010/31/EU recast of the Energy Performance of Buildings Directive (EPBD) states that buildings account for $40 \%$ of the total energy use in the European Union (EU) [1]. However, due to increased trend of using energy efficient products, introduction of renewable energy sources and applications of energy saving policies, the final energy use of the residential sector notes a declining trend in the EU [2]. In order to lower the total energy use of the residential sector, the EU has introduced several energy saving policies to the member states at the local, regional, national and European level. The policies are meant to serve as means for keeping and securing the descending trend of the energy use by the residential sector.

The current long term energy targets set by the European Commission are contained within "The 2030 climate and energy framework" [3]. According to this policy, the member countries of the EU are asked to locally apply strategies that will lead to at least: $40 \%$ cuts in the greenhouse gas emissions from the 1990 levels, $32 \%$ share of renewable energy and $32.5 \%$ improvement in energy efficiency. As a result, fossil fuel powered factories are either closing down or changing their energy source across the Europe. Moreover, the 2020 energy transition analysis made by Ember and Agora Energiewende institutes showed that renewable energy sources currently dominate the electricity production in the EU with the share of $38.2 \%$ [4]. In order to secure the descending trend in the energy use and security of the green sources, alternative technologies are seizing a prominent role in the future energy perspectives. 
Hydrogen $\left(\mathrm{H}_{2}\right)$ gas can serve as an energy carrier and can be produced by means of renewable energy sources. In fact, locally, hydrogen can be produced with excessive generation of electricity obtained from the renewable sources through water electrolysers and further stored efficiently with minimal losses in pressurized (pressures of 350-700 bar) steel or composite tanks [5]. In the context of residential buildings, hydrogen can be used as a fuel source for powering a fuel cell unit, which can provide heating and electrical energy for meeting the common energy demands of the households. A case study research work performed by Lokar and Vitric [6] has shown the potential of integrating hydrogen powered fuel cell as part of the residential building system involving electricity production out of photovoltaic panels and battery storage systems. Their research has shown a promising increment of self-sustainability of the particular case building which leads to lower dependency on the grid electricity source and to the favourable economic advantages reflected for the end user in reduced energy bills.

\subsection{What is a fuel cell?}

A fuel cell (FC) is an electrochemical device that converts the chemical energy of a fuel directly into electrical energy [7]. The FC consists mainly out of three components: a fuel electrode (anode), an oxidant electrode (cathode) and an electrolytic membrane. There are multiple different types of fuel cells which may be distinguished according to the used gas type, types of electrolyte and other material and as well as the operating temperatures. The types that are mostly used today are: alkaline fuel cells (AFC), phosphoric acid fuel cells (PAFC), molten-carbonate fuel cells, solid oxide fuel cells (SOFC) and high/low temperature proton exchange membrane (PEM) fuel cells [7].

PEM fuel cells are specifically interesting for residential buildings since they operate in a temperature range between $30^{\circ} \mathrm{C}$ to $100^{\circ} \mathrm{C}$ [8] which is appropriate for household conditions. In Fig. 1 a schematic representation of a typical composition of a PEM fuel cell stack can be seen.

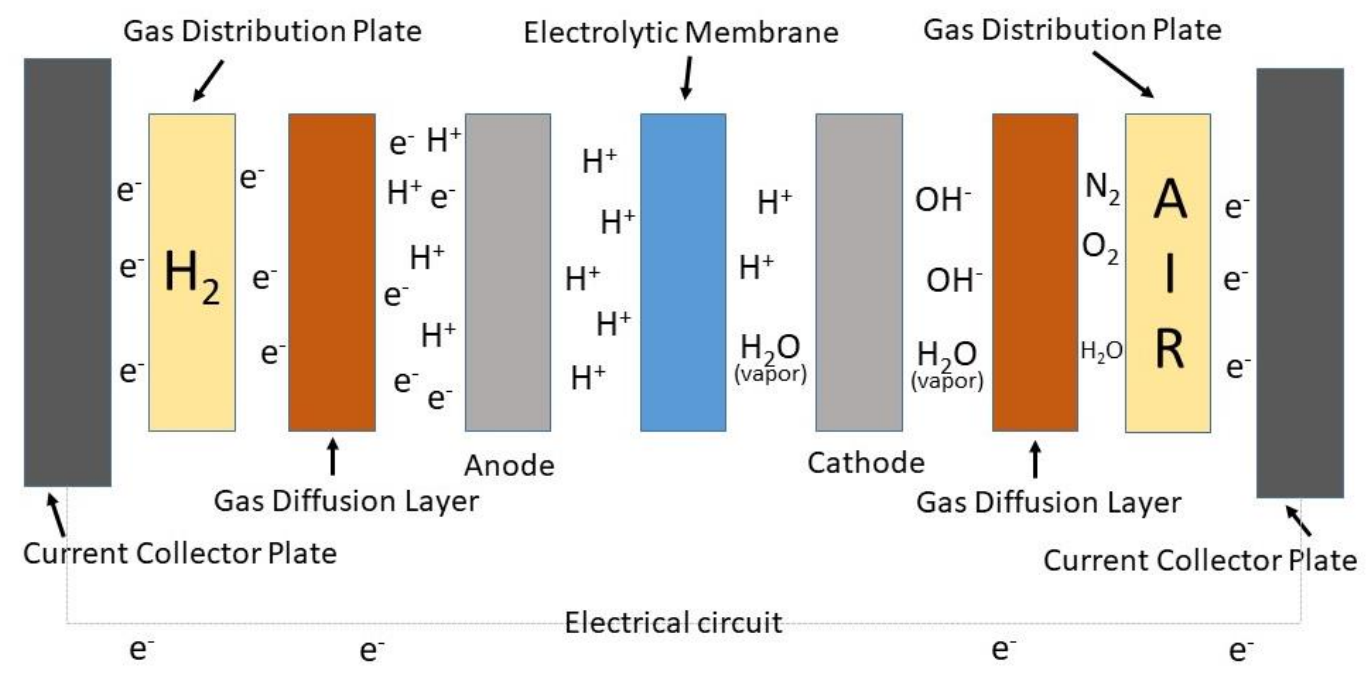

Fig. 1. Illustration of the different PEM fuel cell stack components and a general operating principle.

Typically, a PEM fuel cell is composed out of two electrodes, two gas diffusion layers and an electrolytic membrane conducting protons [9]. In the PEM fuel cells, pure molecular gaseous hydrogen $\left(\mathrm{H}_{2}\right)$ is used as the fuel and it is supplied at the anode side of the fuel cells through the gas distribution plate. At the anode side, $\mathrm{H}_{2}$ undergoes an oxidizing reaction, and forms hydrogen ions $\left(\mathrm{H}_{+}\right)$and electrons $(\mathrm{e}-)$. The formed hydrogen ions migrate through the electrolytic membrane (active layer) to the cathode side of the fuel cell while the electrons bypass this membrane through an external electrical circuit generating electricity. A fuel cell membrane must exhibit relatively high proton conductivity, must present an adequate barrier to the mixing of fuel and reactant gases, and must be chemically and mechanically stable in the fuel cell environment [10]. On the other side of the membrane (the cathode side), the electrons and the migrated hydrogen ions are consumed together with the supplied oxygen (often air or water) to form water in either vapour or liquid state. The reactions taking place within a fuel cell stack thus have the ability to perform work due to the flow of electrons and also to generate a certain amount of heat which can be further exploited. 


\subsection{Efficiency of fuel cells}

The efficiency of fuel cells is not limited by the Carnot efficiency, but rather by the ratio of the Gibbs free energy to the enthalpy of formation of the reacting components [7]. In theory, converting hydrogen and oxygen into water within in a fuel cell unit results in a theoretical maximum efficiency of about $83 \%$. In practice, the efficiency of a PEM fuel cell ranges between $30-40 \%$ [8] and it is caused by different types of voltage drops that are depicted in Fig. 2.

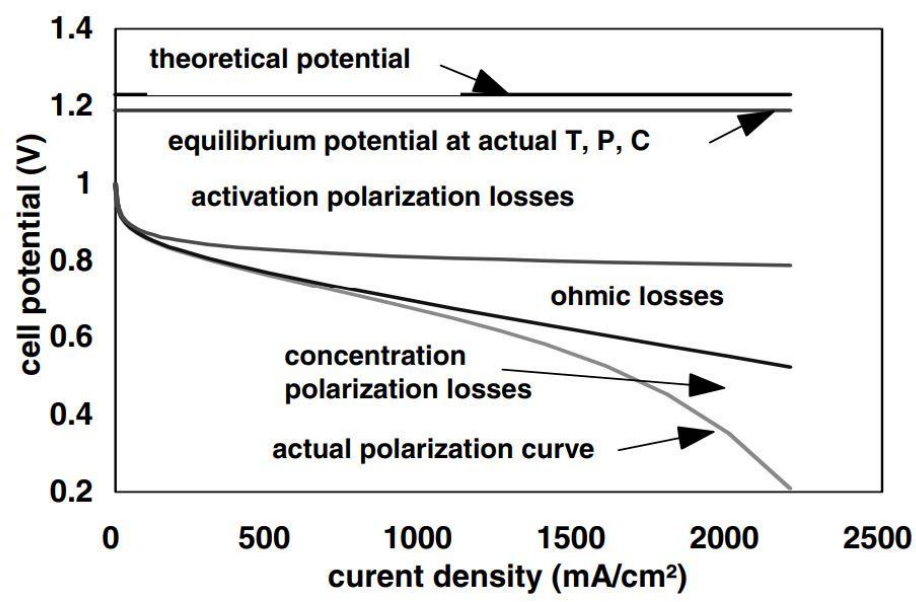

Fig. 2. Various voltage drops and resulting polarization curve of an operating PEM fuel cell [11].

Power losses can mainly be divided between those that originate from the initial voltage drops, related to the operating non-standard pressure and temperature conditions, and three other losses: activation loss, ohmic loss and concentration loss. Instead of using the absolute current value, the losses are often presented as a function of the current density with the goal of contributing to the distinctions in fuel cell sizes and to indicate the possible electricity production potential. Hence, Fig. 2 gives all three losses as a function of the current density extracted from the fuel cell. Equation (1) gives a mathematical overview of the typical fuel cell losses:

$$
E=E_{\text {Nernst }}-E_{\text {Act }}-E_{\text {ohm }}-E_{\text {Conc }}
$$

The theoretical maximum voltage as a function of the partial pressures of the reactants is given by the Nernst equation [12]. The Nernst equation results in a cell potential which is constant with respect to the current density. The other three losses result in a decreasing cell potential with increased current density value.

The activation losses arise from the activation energy required to initiate the chemical reaction at both the anode and cathode side of the fuel cell. The activation losses are described by the Butler-Volemer equation [11]. The ohmic losses are the result of the Joule's conductors heating principle in the fuel cell. It is thus described by Ohm's law and increases linearly with increasing current density values [12]. The concentration loss is the result of a concentration boundary layer as the reactants are rapidly consumed at both the cathode and anode side of the fuel cell stack.

To evaluate the economic feasibility of a fuel cell for the use in the residential sector, the efficiency of the fuel cell is a key parameter. However, the manufacturers of the commercial available fuel cells only supply a single efficiency value to indicate its performance. Therefore, the main goal of this paper is to investigate the trend of the efficiency-current curve for the experimentally evaluated commercially available PEM fuel cell unit. The commercially available fuel cell contains power electronics as well as internal controls, which vastly influence the performance of the unit. Hence, the performance of the unit is analysed in both the steady state and dynamic operating conditions. As a conclusion to this work, an analysis on the practical integration of this particular PEM fuel cell in a modern residential building system installations is carried out.

\section{Description of the experimental setup}

For the purpose of this research, a full experimental test rig was constructed to evaluate the performance of a commercially available PEM fuel cell unit. The evaluated fuel cell unit is a model FCM-802 provided by the British company Intelligent Energy [13]. Table 1 gives an overview of the rated properties of the particular fuel cell unit. The fuel cell has two operating modes at $24 \mathrm{~V}$ and $48 \mathrm{~V}$. At the operating regime of $48 \mathrm{~V}$, this fuel cell unit can generate the rated electrical power of $2.4 \mathrm{~kW}$. Since the voltage value of $48 \mathrm{~V}$ will be used in the residential household application, the same voltage was experimentally analysed at the tested measurements points. 
Table 1. Rated properties of the FCM-802 fuel cell as declared by the company Intelligent Energy [13].

\begin{tabular}{ll}
\hline Characteristic & Value \\
\hline Type & IE FCM-802 \\
Rated net power & $2.5 \mathrm{~kW}$ at $48 \mathrm{~V}$ \\
Rated current & $52 \mathrm{~A}$ at $48 \mathrm{~V}$ \\
Fuel & $99.9 \%$ gaseous hydrogen or better \\
Fuel consumption & Less than $70 \mathrm{~g}$ per kWh \\
Emission & Water vapour \\
\hline
\end{tabular}

In Fig. 3, a simplified overview of the fuel cell test setup is shown. To operate the fuel cell the provision of three items are necessary. Firstly, the fuel cell must be supplied with reactants hydrogen and oxygen. The oxygen is drawn from the ambient air, which should have the temperature between $5^{\circ} \mathrm{C}$ to $40^{\circ} \mathrm{C}$ and a relative humidity between $10 \%$ to $90 \%$. The supplied hydrogen must have the highest quality in terms of constituting compounds. The purity of $99.9 \%$ or higher is required at the hydrogen supply line of the hydrogen. If the supplied hydrogen has a lower purity level, the full cell's internal sensors and controllers may stop the intake of fuel and thus the operation of the unit. The action is a safety measure with the goal to protect the congestions of the fine pores of the fuel stack cells especially the electrolytic membrane. Therefore, in this experiment, the pure $99.9 \%$ hydrogen is supplied from a pressurized 200 bar vertical tank (industrial product of Air Liquide [14]). Since the required gauge inlet hydrogen pressure is only of up to $650 \mathrm{mbar} \pm 150$ mbar, a pressure regulator was used to adapt the high storage pressure to an applicable hydrogen pressure within the operating supply range of the fuel cell.

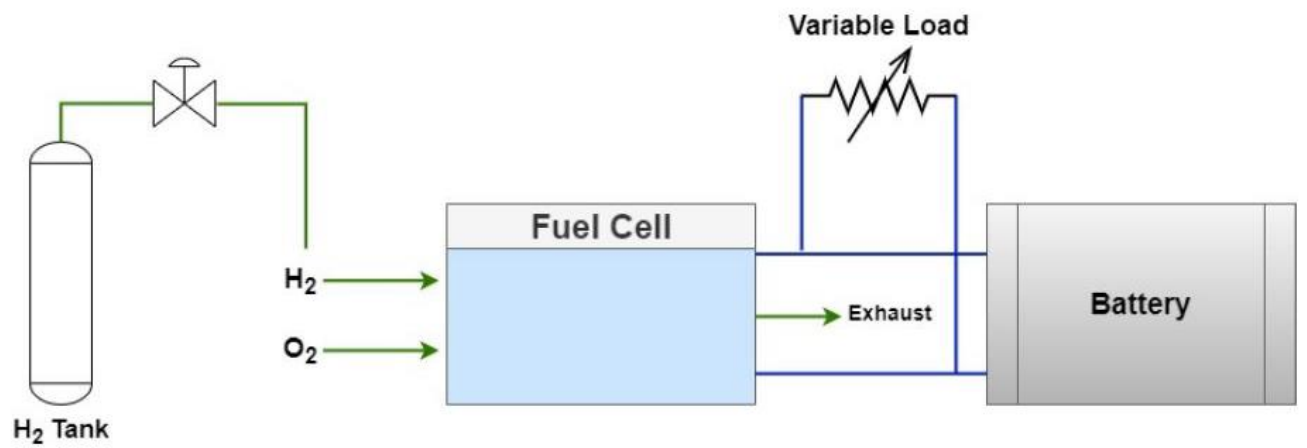

Fig. 3. Schematic overview of the fuel cell experimental test rig.

Secondly, the fuel cell requires an adaptable load which allows the testing of different current density values. The applied load consists of 13 resistances of each $4.7 \Omega$ and a capacity to dissipate $750 \mathrm{~W}$. The 13 resistances are connected in parallel, which allows for a load in the resistance range of $0.36 \Omega$ to $4.7 \Omega$. In addition, two larger resistances of $22 \Omega$ and $47 \Omega$ were added at the load circuit as a possibility analyse the limits of the fuel cell unit. The rated current for $48 \mathrm{~V}$ is $50 \mathrm{~A}$ with a maximum allowable current of $80 \mathrm{~A}$. All resistors are thermally insulated with a ceramic shell. The complete resistance block is shown in Fig. 4.

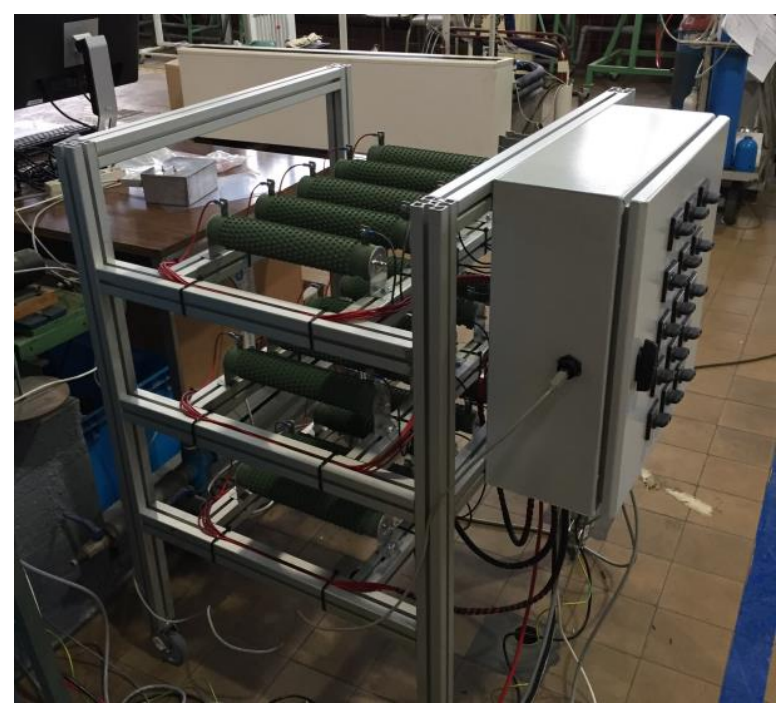

Fig. 4. Used electrical resistors for enabling the variable load operation of the fuel cell. 
The third and last requirement, is a battery pack connected in parallel with the fuel cell unit. The battery in this setup comprises four batteries of $12 \mathrm{~V}$ each that are connected in series to have an equivalent of $48 \mathrm{~V}$. The model Xtreme start 31MF of the company Battery Supplies is the type that is used in the setup [15]. Each battery has a capacity of $100 \mathrm{Ah}$ (C20), which is the current it can deliver for 20 hours at $27^{\circ} \mathrm{C}$ without falling below $10.5 \mathrm{~V}$ [16]. This battery pack is used to supply a continuous power to the load and thus aids the performance of the fuel cell in two operating moments: when the fuel cell is starting up and during the optimization cycle. At the start up, a power input of $32 \mathrm{~W}$ is necessary to run the three fans that blow ambient air into the fuel cell stack and consequently initiate the chemical reaction. Furthermore, the battery pack covers drops in power generation of the fuel cell while it is performing an optimization cycle (which will be elaborated further on in the text). The battery thus acts as a power buffer. Lastly, the battery pack can assist the fuel cell to overcome peak demands of the load. In this case, both the fuel cell and the battery are assumed to be able to deliver power peak loads. Fig. 5 depicts the used battery package.

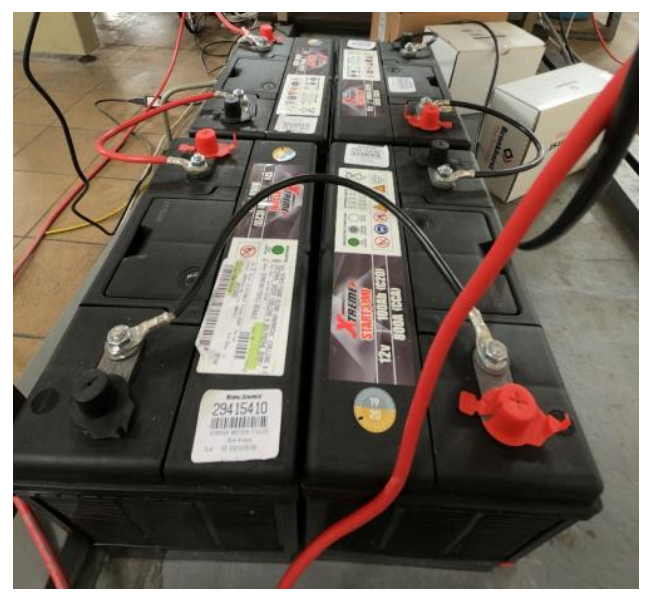

Fig. 5. Four car batteries of $12 \mathrm{~V}$ connected in parallel electrical circuit.

\section{Performance evaluation and data acquisition equipment}

The main goal of the setup is to determine the efficiency of the fuel cell under a variable load as well as to understand the respective operation of the unit. The efficiency of the fuel cell is the ratio of the electrical work output to the chemical energy input of the fuel cell as expressed by Eq. (2):

$$
\eta=\frac{W_{e l}}{W_{H_{2}}}=\frac{V \cdot I}{H H V_{H_{2}} \cdot \dot{n}}
$$

Since the fuel cell supplies DC power, the electrical work output $W_{e l}$ is given by the voltage over the fuel cell $(V)$ times the current output of the fuel cell $(I)$. The chemical energy input is the difference in formation enthalpy between the reactants and products of the underlying chemical reaction in the fuel cell $\left(H H V_{\mathrm{H}_{2}}\right)$. At the standard reference pressure and temperature conditions of $1 \mathrm{~atm}$ and $25^{\circ} \mathrm{C}$ respectively, this value corresponds to 286 $\mathrm{kJ} / \mathrm{mol}$ including the latent heat of condensation of the water vapour. Thus, the value corresponds with the higher heating value of hydrogen. Finally, $\dot{n}$ is the mass flow rate of hydrogen expressed in moles per second. Therefore, in order to obtain the efficiency value of a fuel cell, monitoring equipment for establishing the parameters given in Eq. (2) needs to be installed and digitally acquired.

\subsection{Hydrogen chemical monitoring circuit}

The mass flow rate of hydrogen can be determined by measuring the pressure, volume flow rate and temperature through the ideal gas law. As stated before, the hydrogen is supplied between $500 \mathrm{mbar}$ and 800 mbar gauge pressure with a temperature between $18-35^{\circ} \mathrm{C}$. The ideal gas law is thus defined by Eq. (3) for expressing the value of the molar flow rate:

$$
\dot{n}=\frac{p \cdot \dot{V}}{R \cdot T}
$$

The pressure $p$, the volume flow rate $\dot{V}$ and the temperature $T$ needs to be measured at the hydrogen inlet of the fuel cell. $R$ is the universal gas constant $8.314 \mathrm{~kJ} /(\mathrm{kmol} \mathrm{K})$. Fig. 6 shows an overview of the measured state properties of gaseous inlet and outlet sides of the fuel cell. 


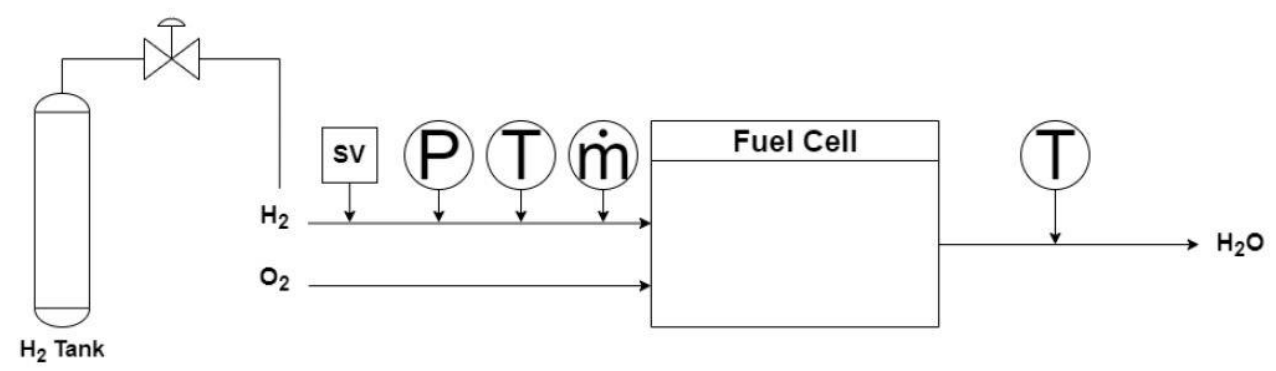

Fig. 6. Illustration of the experimental measurements at the gaseous inlet and outlet side of the fuel cell.

The pressure in the $\mathrm{H}_{2}$ supply line is measured using a Georgin pressure transmitter [17] and the volume flow rate using a Bronkhorst El-Flow select F-111AC meter [18]. In Fig. 6, the instrument with the mark "SV" represents the safety on/off valve, which stops the supply of hydrogen if a leakage is detected. This safety feature is required due to the high inflammably of the hydrogen. The temperature of the $\mathrm{H}_{2}$ is measured by submerging a K-type thermocouple directly into the $\mathrm{H}_{2}$ supply line while a T-type thermocouple is placed at the exhaust of the fuel cell. Both thermocouples are calibrated using a Pt100 and an insulated cold junction to an accuracy of $0.1 \mathrm{~K}$.

\subsection{Electrical monitoring circuit}

An overview of the measuring points at the electrical circuit side of the fuel cell may be seen in Fig. 7. In order to estimate the current flow and interaction between the fuel cell, buffer battery and the load, the current value is measured twice at this setup.

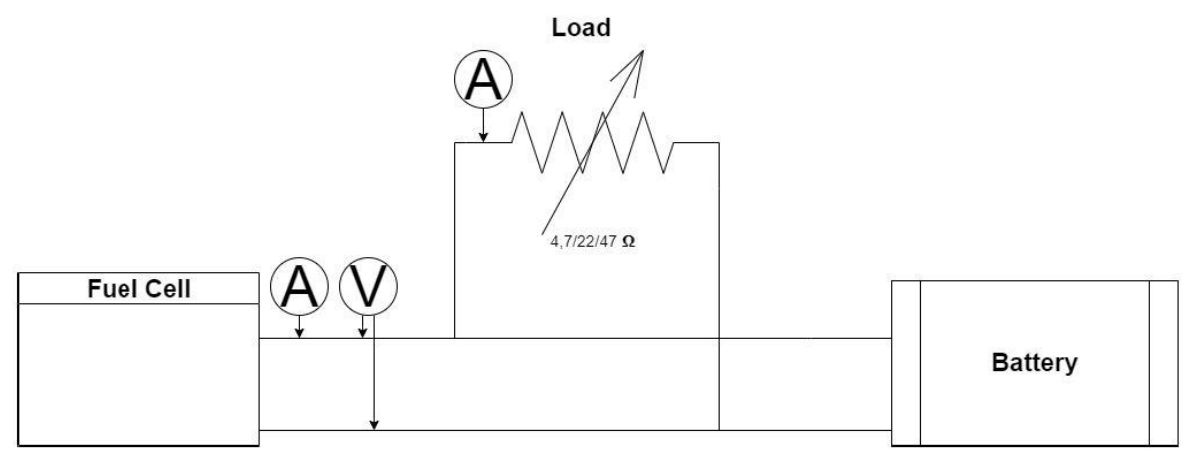

Fig. 7. Illustration of the experimental measurements made on the electrical circuit of the fuel cell.

At first, the electrical current output of the fuel cell is measured internally by the fuel cell's internal equipment and can be read through the CAN interface of the IE FCM-802. The current to the load is determined by measuring the voltage over a shunt resistance with the known resistance of $250 \mu \Omega$. The voltages are measured using a Keithley 2010 multiplexer. In this way, both the generated current and the actual current over the load could be monitored which allowed the understanding of when the fuel cell is delivering power, when it is consuming power and whether the power is supplied to the resistances or the battery pack.

\section{Results, experimental test measurements}

In this work, several experiments have been conducted in order to examine the performance of the PEM fuel cell. Each experiment is carried out following the same procedure. Firstly, a load is applied to the battery pack and fuel cell after which the fuel cell is turned on. During the operation, the fuel cell will periodically perform cycle optimizations. At such a cycle optimization, the current delivered by the fuel cell will drop to nearly zero and the power to the load is maintained by the battery pack.

Fig. 8 shows the voltage over the fuel cell and the current to the fuel cell during one of the optimization cycles. As observed, the current drops very quickly to zero for a couple of seconds. Within about four seconds, after the start of the cycle, the current begins to rise again to a value which is higher than at the start of the optimization cycle. Subsequently, the current is approximately exponentially reduced to a constant value. As mentioned, during the short blackout provoked by the optimization cycle, the battery pack takes over the power supply to the load. The fuel cell is able to compensate the lost energy from the battery after its output current is sufficiently high again. The battery is considered to be charged with the power peak of the fuel cell right after the its current value recovery. On the other hand, the voltage is significantly less susceptible to the optimization cycle and it remains rather constant. 


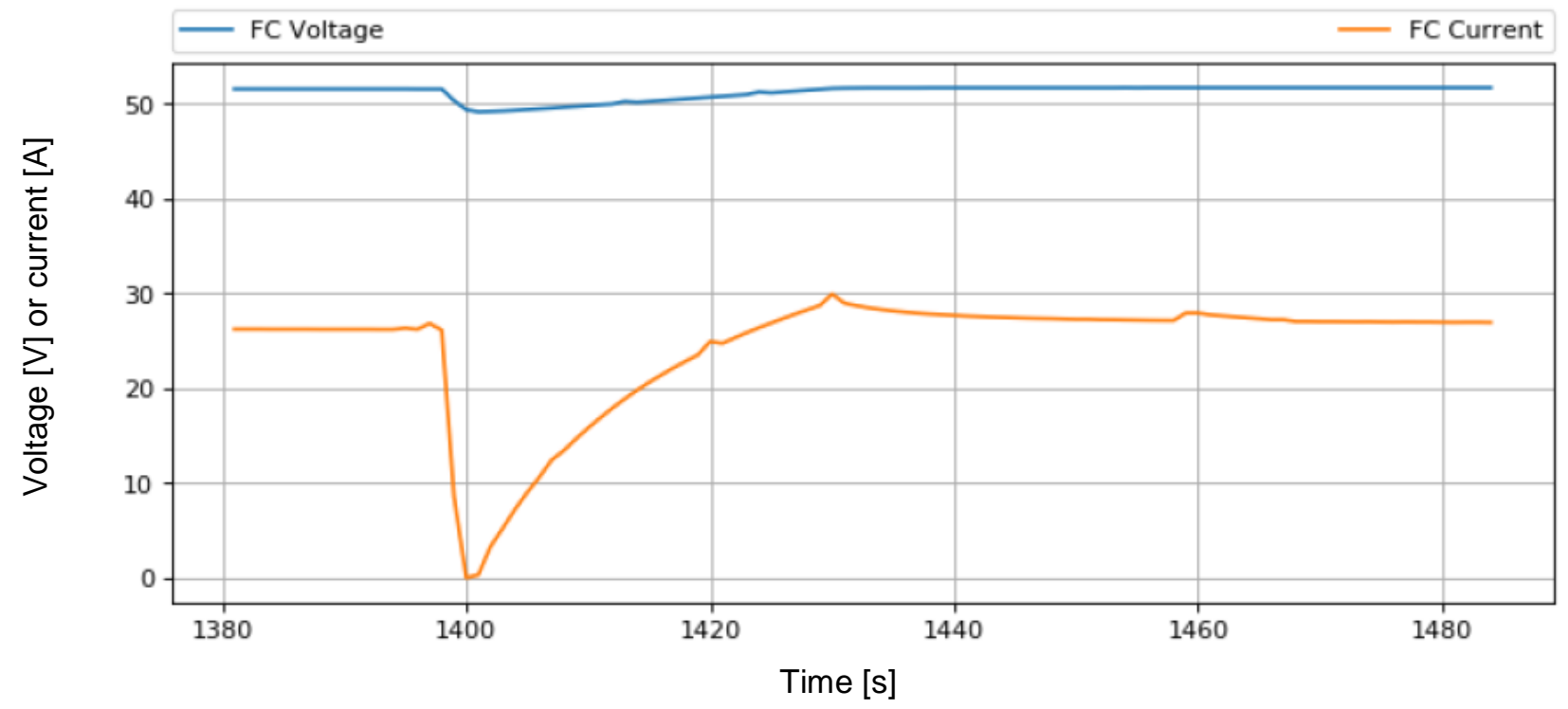

Fig. 8. Voltage and current delivered by the fuel cell during an optimization cycle.

The resulting voltage and current values for a full test are shown in Fig. 9. The full test starts with 4 applied resistances after which the load was turned off and on again at the load of 8 resistances which were gradually added. At the start of the experiment, the fuel cell draws energy from the battery pack. On average, $32 \mathrm{~W}$ is drawn from the battery for about 15 seconds to power up the fans and other operational electronics of the fuel cell. Besides, during the start-up, the battery is required to provide the power to the load during each optimization cycle. Depending on the applied load at that time, the battery needs to deliver its power for approximately 12 seconds which may be as high as $2850 \mathrm{~W}$. The optimization cycle is performed four times at the start up, and then periodically during the remainder of the cycle. These four optimization cycles improve the fuel cell efficiency by about $4 \%$ in comparison to the initial efficiency of the unit. According to the official user manual of the unit, the optimisation cycles occurs less than 15 times an hour during operation [13].

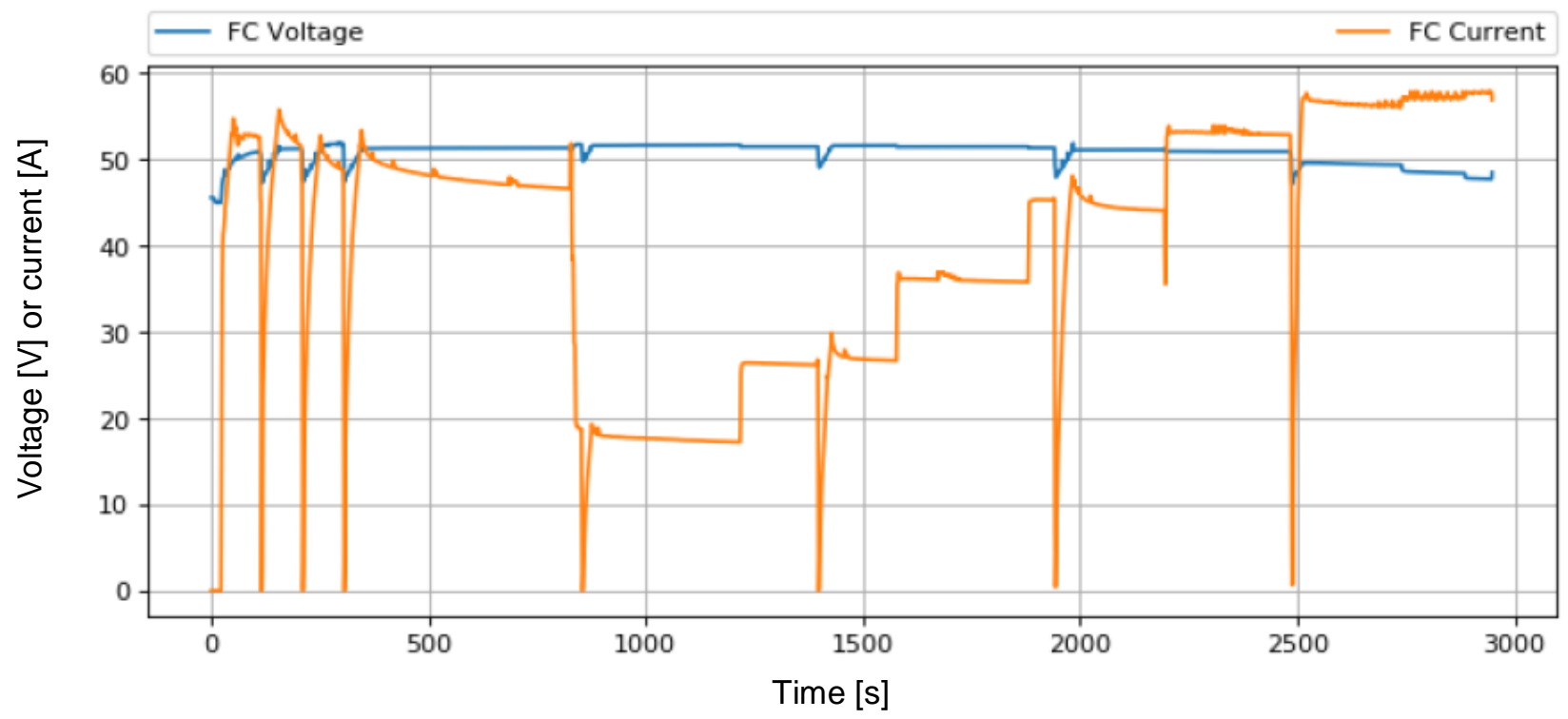

Fig. 9. Voltage and current delivered by the fuel cell during a full test sequence with varying applied resistive loads.

Due to the optimization cycle, the voltage over and current from the fuel cell are not constant in time. Therefore, the current and voltage are averaged in time for each resistive load where the optimization cycles themselves were excluded from the averaging window. The resulting averaged voltage and current are shown in Fig. 10 for a series of eight tested resistances. 


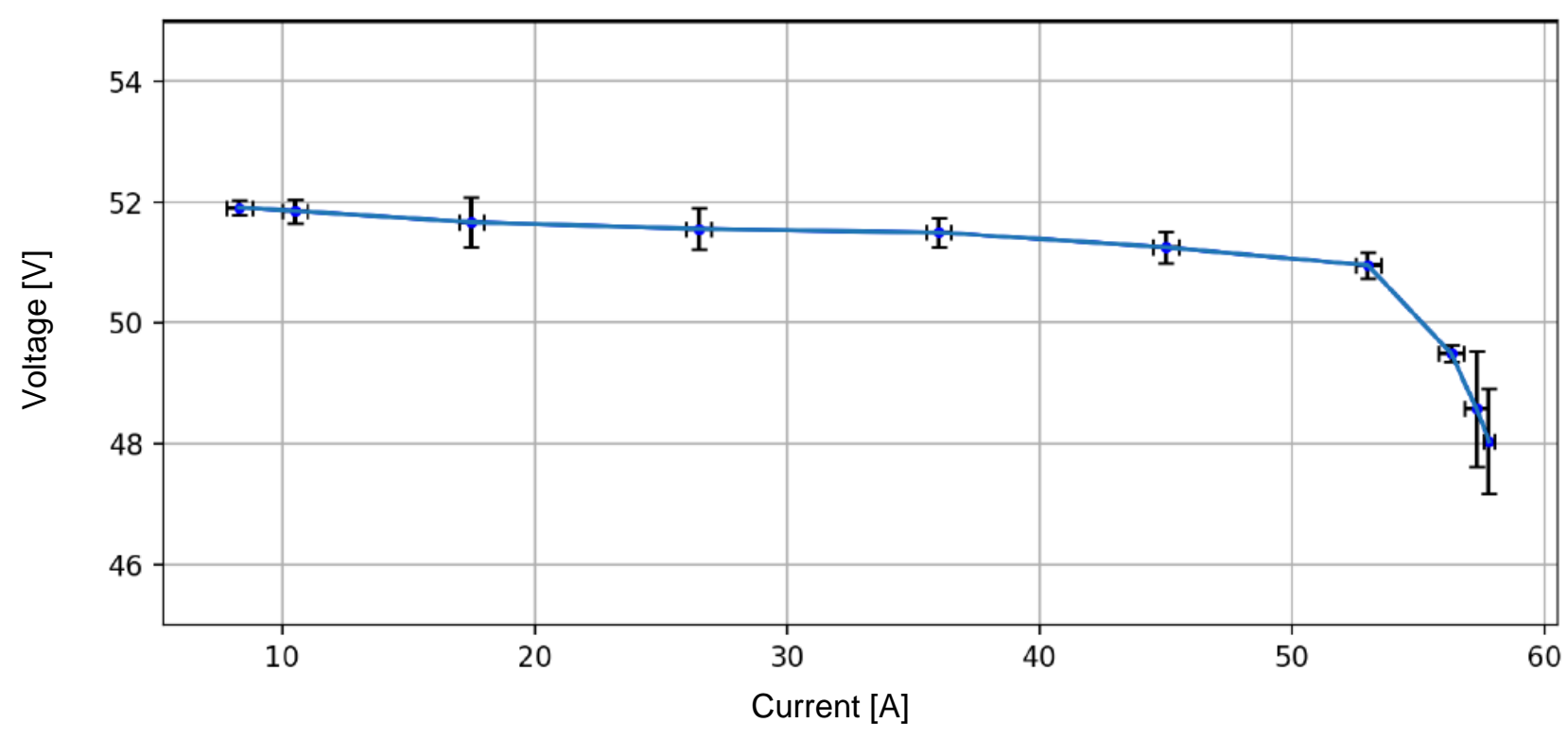

Fig. 10. Voltage as a function of the current delivered by the fuel cell for 8 applied loads.

The test shown in Fig. 10 is repeated an additional two times to verify the repeatability of the findings (i.e the averaging affects). Fig. 11 shows the results of these three tests, which do not differ significantly. The red colour represents the results of 5 connected resistances, the green 7 , while the blue coloured curve gives the result for 8 resistances connected in parallel.

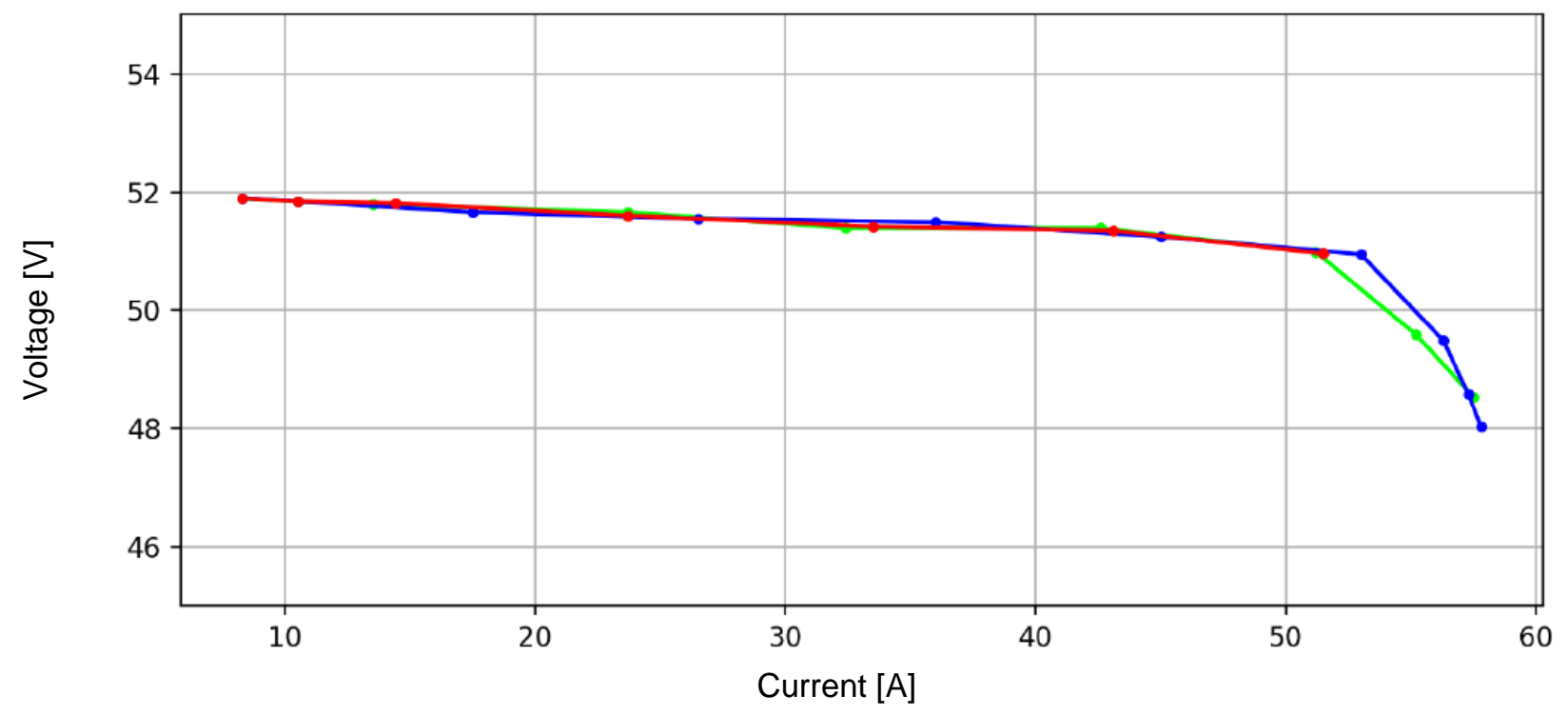

Fig. 11. Repeatability test for the voltage as a function of the current delivered by the fuel cell.

The voltage as a function of the current shown in Fig. 10 deviates from what would be expected from the theory of a fuel cell outlined in the introduction. A reason for the deviation with the theoretical curve is the fact that the theory only considers a single fuel cell while the tested commercial fuel cell contains an array of individual connected cells. Furthermore, power electronics are required to obtain the relatively stable output voltage of the fuel cell. As a result, the behaviour of the commercial unit is far more the result of the internal power electronics and connection of the fuel cells than the theoretical functioning of a hydrogen fuel cell.

However, some phenomena of the voltage current density curve can be explained based on the theoretical losses described in the introduction. The gradual drop in supplied potential can be explained by ohmic losses while the drop at the end of the voltage curve can be explained by concentration polarization losses.

Fig. 12 shows the efficiency of the fuel cell as a function of the load. There is no significant change in the fuel cell efficiency as a function of the load. The official manual of the fuel cell states a minimal efficiency of $36.2 \%$ for a new fuel cell. The stated efficiency is not significantly different from the measured one. However, for the 
performed tests and applied monitoring equipment, the examined fuel cell could not reach the declared efficiency of $36.2 \%$. Still, the declared efficiency is noted within the error margin of the used equipment.

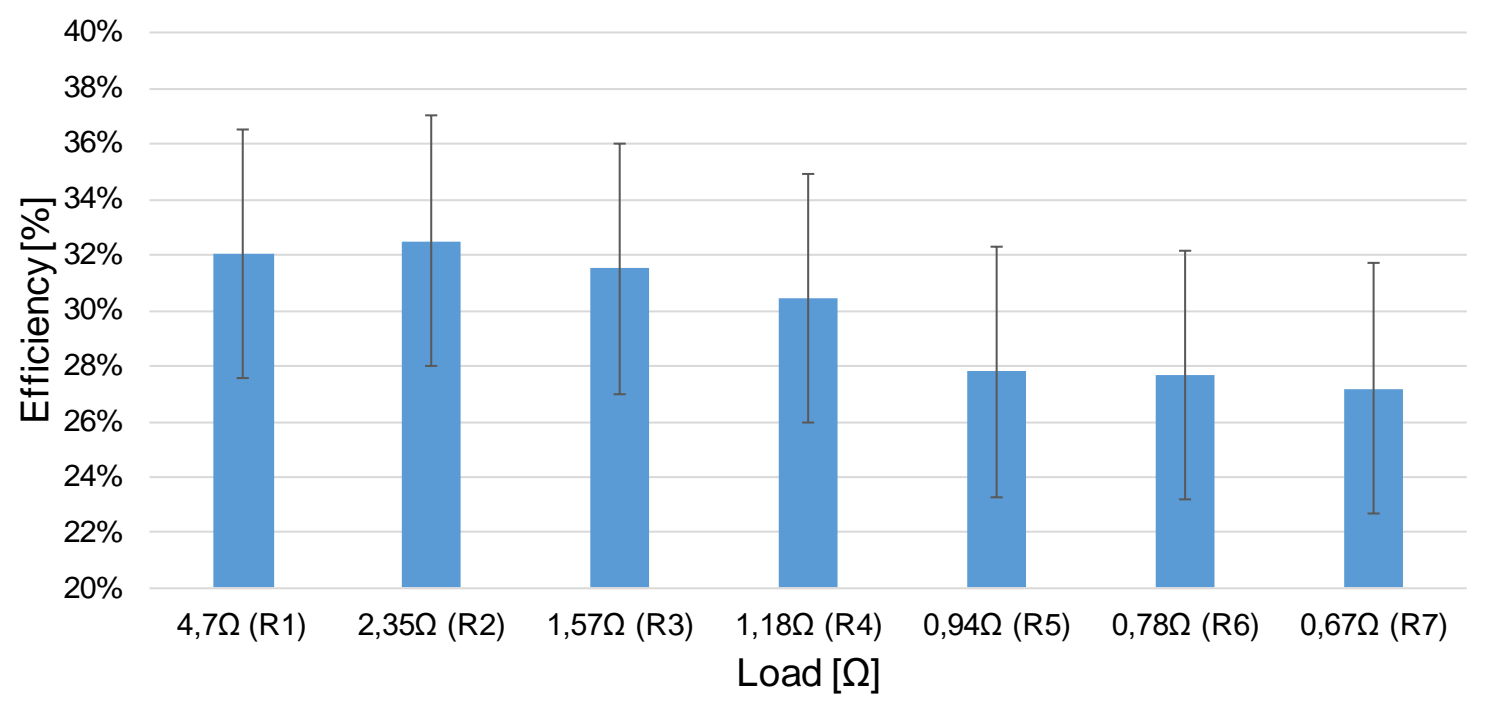

Fig. 12. Efficiency of the fuel cell as a function of the load.

In Fig. 13 the measured exhaust temperature as a function of the applied resistive load can be seen. The exhaust temperature does not strongly fluctuate with the load. Furthermore, the exhaust air temperature is found to be too low to perform any additional cost effective heat recovery from the unit besides directly using the exhaust air. Thus, the performed tests made in this research have proved the irrationality of using the waste heat generated by the analysed PEM fuel cell unit.

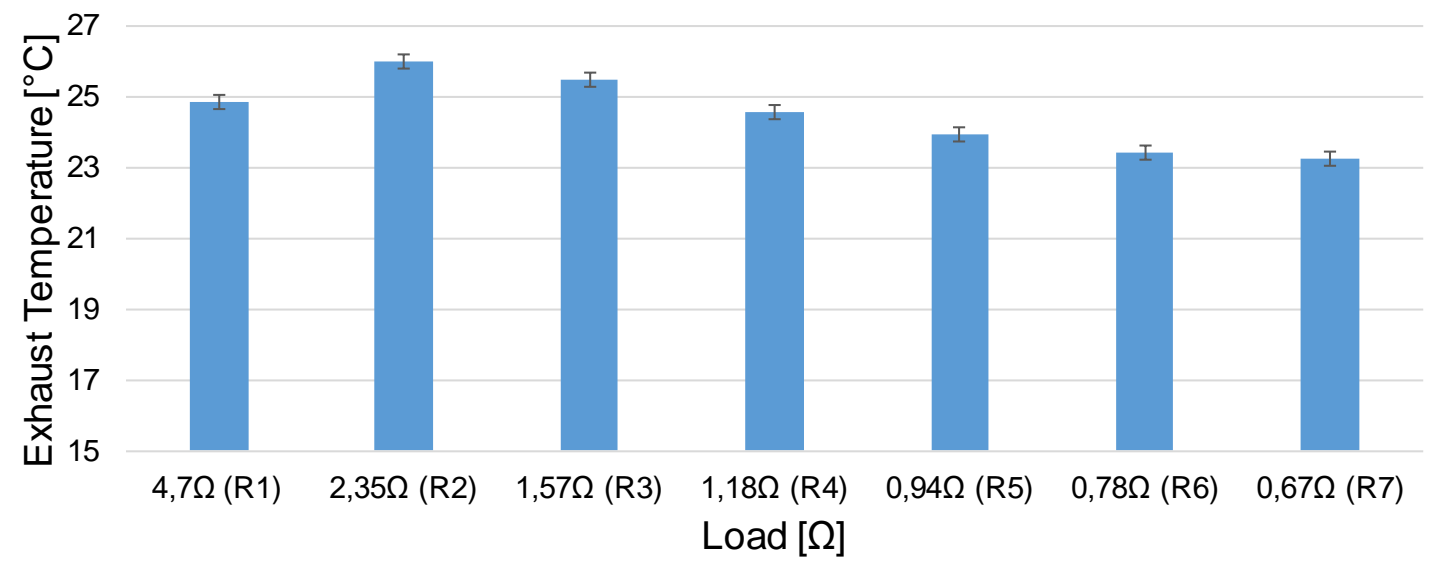

Fig. 13. Exhaust temperature as a function of the resistive load.

\section{Practical application and future perspectives}

In order to evaluate the concept of a hydrogen based energy storage system using the FCM-802, example data from a case study of an industrial partner was used. The case concerns a modern residential household located in Belgium in which the electrical power is used to supply the complete heating system (space heating and domestic hot water) with a swimming pool, electrical appliances and an electrical vehicle. Fig. 14 gives an illustrated overview of the analysed system.

To cover the electrical energy demand, locally produced renewable energy out of the photovoltaic panels and wind turbine would be used. The shortage of energy production should be compensated from the FCM-802 fuel cell. Based on the input data, the total electricity demand of the household is about $13000 \mathrm{kWh}$ out of which $2331 \mathrm{kWh}$ needs to be covered either from a hydrogen powered fuel cell or from the grid. With the hydrogen's power density of $142 \mathrm{MJ} / \mathrm{kg}$ and declared initial efficiency of the fuel cell unit, the total amount of stored hydrogen necessary for covering the electricity demand is $2132.9 \mathrm{Nm}^{3}$. 


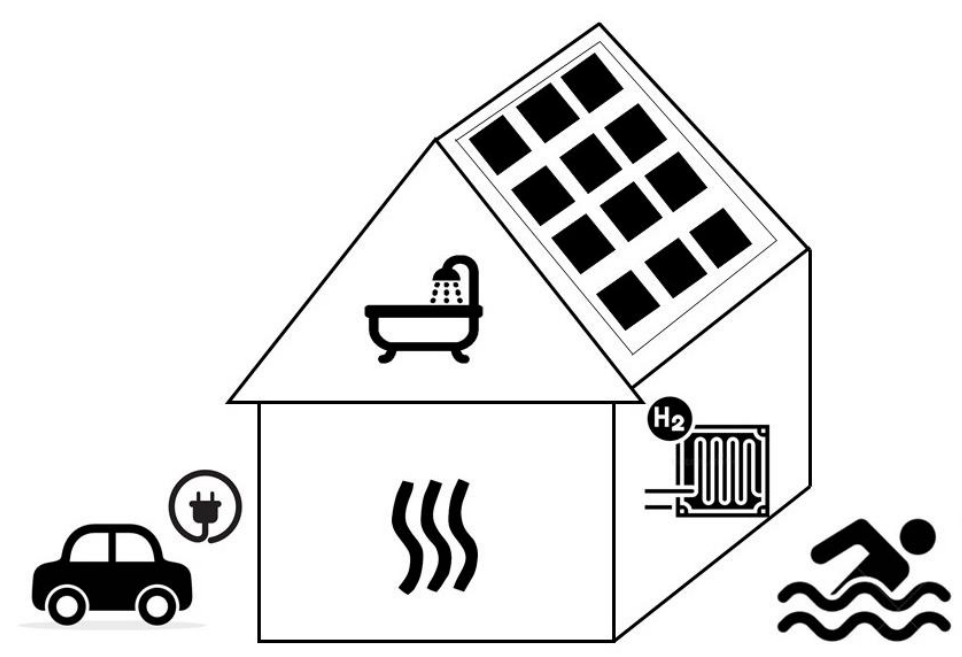

Fig. 14. Graphycal ilustation of the local system application example.

The system design also includes a water electrolyser which is used to produce hydrogen during the summer period when there is a surplus in renewable energy generation. The chosen electrolyser S40 is a product of the company $\mathrm{Nel}$ with the efficiency of $55 \%$ and energy use of $6.1 \mathrm{kWh}$ per $\mathrm{Nm}^{3}$ of produced hydrogen [19]. Besides the electrolyser, a compressor for storing the hydrogen at higher pressures is needed in the system as well. Fig. 15 gives an overview of the efficiencies of the used equipment and hence the overall system efficiency.

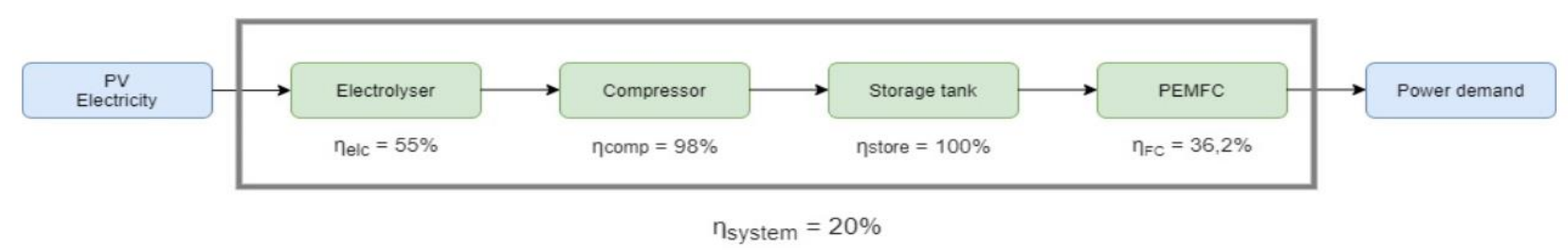

Fig. 15. System efficiency overview.

With the surplus $6069 \mathrm{kWh}$ of electricity, the installed electrolyser can produce $1994.9 \mathrm{Nm}^{3}$ of hydrogen leaving a shortage of $1138.02 \mathrm{Nm}^{3}$. The total system efficiency of the hydrogen storage system is determined based on an assumed efficiency of $55 \%$ for the electrolyser, $98 \%$ for the compressor and the stated $36.5 \%$ for the fuel cell resulting in only $20 \%$. Utilisation of the waste heat of the fuel cell or recovery of unused hydrogen at the exhaust line would lead to an increment of the fuel cell's efficiency and thus improve system's overall efficiency. In this regard, the replacement of the used PEM fuel cell by a fuel cell with higher efficiency and heat production (such as SOFC) can be a better choice for the described system. On the other hand, application of an electrical energy storage with efficiencies of up to $90 \%$ can be used to increase the selfsufficiency of the dwelling. In these conditions, the fuel cell system with the lowest efficiency can be used as the last local generation energy source. However, it is important to mention that the electrical battery cannot be used as a seasonal energy storage unlike hydrogen. In this case, for improved performance, electrical energy storage can be used as daily storage while the surplus of generated energy can be used to produce hydrogen for seasonal use of fuel cells.

In the future, industrial size fuel cells and electrolysers can also be considered as the alternative to the local implementation of the technology. In this way, the system can be permanently operated at the optimal conditions under all necessary safety protocols and supply entire neighbourhoods with heat and electrical power. In addition, such installation can be powered with other renewable energy sources on bigger scales such as wind turbines, PV generation farms and hydropower solutions. The sizing and implementation of such system is a topic of future interest.

\section{Conclusion}

Residential buildings are recognised as one of the biggest energy users of the European Union. With the increased aspirations towards energy savings and decreased use of fossil fuels, the application of hydrogen as a power source of fuel cell units is currently investigated on an extensive level.

In this work, an experimental evaluation of a commercially available proton exchange membrane (PEM) fuel cell has been made. The fuel cell unit was tested for a varying set of resistive loads in order to make a better 
overall understanding of the performance of the unit and its efficiency. The evaluated unit resulted in efficiencies between $27.5 \%$ to $32.5 \%$ while the officially stated efficiency is $36.5 \%$. In combination with a power buffer battery pack, the fuel cell is able to generate electrical power between $400 \mathrm{~W}$ and $2770 \mathrm{~W}$ for a rather stable voltage of $51 \mathrm{~V}$ to $52 \mathrm{~V}$. The fuel cell unit is also characterized by an optimisation cycle that briefly stops the electrical power output (compensated by the battery pack). The optimisation cycle contributes to the improved efficiency of the fuel cell and to the stability of the electrical output. Still, due to its low efficiency, the fuel cell unit contributes greatly to the lower overall system efficiency that resulted to be only $20 \%$ for a residential household system case study. Even though the heat generation of this particular fuel cell is not sufficient for further utilization (average temperature of the exhaust line $25^{\circ} \mathrm{C}$ ), such possibility will certainly contribute to the better efficiency of the unit and thus of the overall system.

\section{Acknowledgments}

The authors would like to express their deepest gratitude and appreciation to the company Callens \& Bruynoghe and its owner Mr Koen Bruynoghe for providing the fuel cell unit that was analysed and for all additional support. Secondly, the authors would like to thank the financial support of the FWO-SBO project Next generation building energy assessment methods towards a carbon neutral building stock, funded by the Research Foundation - Flanders without which the experimental analysis could not be completed.

\section{Nomenclature}

$E$ energy, J

\section{Greek symbols}

$\eta$ efficiency

\section{Subscripts and superscripts}

Act Activation losses

Ohm Ohmic losses

Conc Concertation losses

\section{References}

[1] European Commission. Directive 2010/31/EU of the European Parliament and of the Council of 19 May 2010 on the Energy Performance of Buildings. Official Journal of European Union 2010;13-35.

[2] Tzeiranaki, S. T.,Bertoldi P., Labanca N., Castellazzi L., Ribeiro Serrenho, T., Economidou M., Zangheri P., Energy consumption and energy efficiency trends in the EU-28 for the period 2000-2016; 2018. Technical Report No.: EUR 29473 EN.

[3] European Commission. 2030 climate \& energy framework. - Available at: $<$ https://ec.europa.eu/clima/policies/strategies/2030 en> [accessed: 24.01.2020].

[4] Redl C., Hein F., Buck M., Graichen P., Jones D., The European Power Sector in 2020: Up-to-Date Analysis on the Electricity Transition; 2021 Jan. Technical report No.: 202/02-A-2021/EN

[5] Breeze P., Hydrogen Energy Storage. In: Power System Energy Storage Technologies, Academic press Publisher. 2018. p. 69-77.

[6] Lokar J., Virtič P., The potential for integration of hydrogen for complete energy self-sufficiency in residential buildings with photovoltaic and battery storage systems. International journal Hydrogen Energy 2020;45:34566-34578.

[7] Sharaf O.Z., Orhan M. F., An overview of fuel cell technology : Fundamentals and applications. Renewable and Sustainable Energy Reviews 2014;32: 810-853.

[8] Elmer T., Worall M., Wu S., Riffat S. B., Fuel cell technology for domestic built environment applications: State of-the-art review. Renewable and Sustainable Energy Reviews 2015;42:913-931.

[9] Noguer N., Candusso D., Kouta R., Harel F., Charon W., A PEMFC multi-physical model to evaluate the consequences of parameter uncertainty on the fuel cell performance. International journal Hydrogen Energy 2015;40:3968-3980.

[10] Gottesfeld S., Zawodzinski T., Advances in electrochemical science and engineering. In: Hacker V., Mitsushima S., editors. Polymer Electrolyte Fuel Cells, Elsevier Publisher. 1997.

[11] Barbir F., In: PEM Fuel Cells. Academic Press Publisher, 2005.

[12] O'Hayre R., Cha S. W., Colella W., Prinz F.B., Fuel Cell Fundamentals. Wiley. 2016.

[13] Intelligent Energy. FCM-802/804 User Manual; 2018. Technical report.

[14] Air liquid. - Available at: <https://www.airliquide.com/> [accessed: 24.02.2020].

[15] Battery supplies. - Available at: <https://batterysupplies.be/en/> [accessed: 24.02.2020]. 
[16] autobatteries.com. Reserve capacity and Amp hour (C20). - Available at: $<$ https://www.autobatteries.com/en-us/how-to-choose-your-car-battery-replacement/reserve-capacityc20-amp-hour-ah> [accessed: 25.02.2020].

[17] Georgin pressure transmitter. - Available at: <https://www.georgin.com/measurement> [accessed: 24.02.2020].

[18] Bronkhorst. - Available at: <https://www.bronkhorst.com/int/> [accessed: 24.02.2020].

[19] Nel. S-series: Proton PEM electrolyser. - Available at: <https://nelhydrogen.com/product/s-series/> [accessed: 24.02 .2020 ]. 